\title{
Intractable diseases treated with intra-bone marrow-bone marrow transplantation
}

\author{
Ming Li $^{1}$, Kuquan Guo ${ }^{2}$ and Susumu Ikehara ${ }^{1}{ }^{*}$ \\ ${ }^{1}$ Department of Stem Cell Disorders, Kansai Medical University, Hirakata City, Japan \\ ${ }^{2}$ Department of Cardiac Surgery, Beijing Institute of Heart, Lung and Blood Vessel Disease, Beijing Anzhen Hospital Affiliated to Capital Medical University, Beijing, \\ China
}

Edited by:

Atsushi Asakura, University of Minnesota, USA

Reviewed by:

Hong Zhang, Harvard Medical

School, USA

Simone Pacini, University of Pisa, Italy

\section{*Correspondence:}

Susumu Ikehara, Department of

Stem Cell Disorders, Kansai Medical

University, 2-5-1 Shinmachi, Hirakata

City, Osaka 570-1010, Japan

e-mail: ikehara@hirakata.kmu.ac.jp
Bone marrow transplantation (BMT) is used to treat hematological disorders, autoimmune diseases (ADs) and lymphoid cancers. Intra bone marrow-BMT (IBM-BMT) has been proven to be a powerful strategy for allogeneic BMT due to the rapid hematopoietic recovery and the complete restoration of $T$ cell functions. IBM-BMT not only replaces hematopoietic stem cells (HSCs) but also mesenchymal stromal cells (MSCs). MSCs are multi-potent stem cells that can be isolated from bone marrow (BM), umbilical cord blood (UCB), and adipose tissue. MSCs play an important role in the support of hematopoiesis, and modify and influence the innate and adaptive immune systems. MSCs also differentiate into mesodermal, endodermal and ectodermal lineage cells to repair tissues. This review aims to summarize the functions of BM-derived-MSCs, and the treatment of intractable diseases such as rheumatoid arthritis (RA) and malignant tumors with IBM-BMT.

Keywords: intra-bone marrow-bone marrow transplantation, mesenchymal stem cell, rheumatoid arthritis, malignant tumors, autoimmune diseases

\section{INTRODUCTION}

Mesenchymal stromal cells (MSCs) are multi-potent progenitor cells mainly isolated from bone marrow (BM) (Campagnoli et al., 2001), adipose tissue (Zuk et al., 2001), and the umbilical cord (UC) (Erices et al., 2000). MSCs have been shown to differentiate into osteoblasts, adipocytes (Dominici et al., 2006), cardiomyocytes (Makino et al., 1999), and pancreatic islets (Tang et al., 2004). Furthermore, MSCs have the ability to migrate to injured tissue of liver (van Poll et al., 2008) and heart (Yokokawa et al., 2008). Adipose tissue and BM are the most readily available sources of MSCs because they are easy to harvest, and there are no ethical concerns. BM-derived MSCs (BMMSCs) have a higher degree of commitment to differentiate into chondrogenic and osteogenic lineages than adipose tissue-derived MSCs (Gimble et al., 2007), although there appears to be no difference between adipose tissue-derived MSCs and BM MSCs in terms of immunoregulatory functions and support of hematopoiesis (Poloni et al., 2012). On the other hand, BM MSCs modulate the immune response, suppress allogeneic $\mathrm{T}$ cell responses, and prevent the development of graft-versus-host disease (GVHD) (English, 2013).

BM transplantation (BMT) is useful for treating hematopoietic disorders, allogeneic BMT also being used to treat autoimmune diseases (ADs) (Nishimura et al., 1994). Intra-bone marrow-bone marrow transplantation (IBM-BMT) has been proven to be the most effective approach to treating allogeneic BMT, since IBM-BMT can replace not only hematopoietic stem cells (HSCs) but also BMMSCs Thus hematopoietic recovery is rapid, and no GVHD develops even if whole BM cells are injected (Kushida et al., 2001; Ikehara, 2003). In this review, we focus on rheumatoid arthritis (RA) and malignant tumors treated with IBM-BMT.

\section{IMMUNOREGULATORY FUNCTIONS OF BMMSCs}

BMMSCs have been reported to have the ability to modify and influence almost all the cells of the innate and adaptive immune systems mediated by BMMSC soluble factors, including IL-6, M-CSF, IL-10, TGF $\beta$, HGF, and PGE2 (Aggarwal and Pittenger, 2005; Beyth et al., 2005; Ramasamy et al., 2007). The adaptive immune system, which is composed of $\mathrm{T}$ and B lymphocytes, generates specific immune responses to pathogens with the production of memory cells. BMMSCs modulate the function of dendritic cells (DCs), indirectly regulate $\mathrm{T}$ and $\mathrm{B}$ cell activity, and delay or prevent the development of acute GVHD (Zhang et al., 2009). BMMSCs have also been shown to suppress the differentiation of DCs and their function during allogeneic islet transplantation (Urban et al., 2008; Aldinucci et al., 2010). BMMSCs strongly inhibited the maturation and functioning of monocytederived DCs by interfering selectively with the generation of immature cells via inhibitory mediator of MSC-derived PGE2 (Lee et al., 2006). PGE2 has been identified as one of the candidates responsible for T cell inhibition by BMMSCs, and may have an immunostimulatory role by facilitating Th1 differentiation and expanding the Th17 $\mathrm{T}$ cell population (English et al., 2009; Yao et al., 2009). The expression of PGE2 was shown to be upregulated by IFN $\gamma$ and TNF $\alpha$ in the BMMSCs for immunomodulatory function (English et al., 2007). BMMSCs can inhibit the cytotoxic effects of antigen-primed cytotoxic $T$ cells by suppressing the proliferation and activity (Zhao et al., 2005) via the inhibition of the nuclear translocation of nuclear factor-kappa B (Matsuda-Hashii 
et al., 2004). BMMSCs have been shown to alter the NK cell phenotype and suppress proliferation of NK cells via the secretion of TGF $\beta 1$ and PGE2, and via cytotoxicity against HLA class I-expressing targets (Aggarwal and Pittenger, 2005; Sotiropoulou et al., 2006; Ryan et al., 2007; Uccelli et al., 2008). BMMSCs have also been shown to inhibit the proliferation of $\mathrm{B}$ cells when stimulated with anti-CD40L and IL-4 (Glennie et al., 2005). One report has suggested that allogeneic BMMSCs inhibit the activation, proliferation and IgG secretion of B cells in a BXSB mouse model of human systemic lupus erythematosus (Deng et al., 2005).

Allogeneic BMMSCs are effective in the treatment of murine models of human disease (Zappia et al., 2005; Ding et al., 2009; Fiorina et al., 2009). BMMSCs were shown to be able to secrete regulatory cytokines that affect regulatory $\mathrm{T}$ cells, and to modulate the immunological dysregulation observed in antibody producing $\mathrm{B}$ cells and cytotoxic NK cells in the NOD mouse (Anderson and Bluestone, 2005). BMMSCs promote the endogenous repair of pancreatic islets and renal glomeruli in a streptozotocin-induced diabetic mouse model (Lee et al., 2006). Co-infusion of BMMSCs and BM cells was shown to inhibit the beta cell-specific $\mathrm{T}$ cell proliferation and to restore insulin and glucose levels (Urban et al., 2008). BMMSCs secrete many cytokines and growth factors such as HGF, which shows anti-apoptotic activity in hepatocytes and plays an essential part in the regeneration of the liver (Trim et al., 2000; Matsuda-Hashii et al., 2004). BMMSCs have also been shown to protect against experimental liver fibrosis in CCl4-induced rats (Zhao et al., 2005), and to suppress CD3 T-cell proliferation in collagen-induced arthritis (Schurgers et al., 2010).

In mammals, there are seven sirtuin family members, named Sirt1-7. Sirtuins plays a critical role in the regulation of fundamental biological responses to nutritional and environmental stimuli in each subcellular compartment (Blander and Guarente, 2004; Imai and Guarente, 2010). Sirt1 is a class III protein deacetylase, and Sirtl activity can be regulated through $\mathrm{NAD}^{+}$. Sirt1 binds to and deacetylates a number of important transcription factors-such as peroxisome proliferator-activated receptor gamma $(\operatorname{PPAR} \gamma), \operatorname{PPAR} \alpha, \operatorname{PPAR}$ gamma coactivator 1 alpha (PGC-1 $\alpha$ ), and the forkhead box, subgroup O (FOXO) family of transcription factors-to drive metabolic responses such as insulin secretion, gluconeogenesis, and fatty acid oxidation (Haigis and Sinclair, 2010). Some reports indicate that Sirt1 promotes osteogenesis and decreases adipogenesis of BMMSCs in vitro (Tseng et al., 2011; Peltz et al., 2012; Puri et al., 2012).

Sirt1 deacetylates $\beta$-catenin to regulate differentiation of MSCs in MSCs specific Sirt1 knock-out mice (MSC KO) (Simic et al., 2013). Moreover, Sirt1 has been shown to directly downregulate Sost gene expression, and promote bone formation in the treatment of osteoporosis (Cohen-Kfir et al., 2011). One report has shown that CD8 $\mathrm{T}$ cell differentiation is regulated by basic leucine zipper transcription factor, ATF-like (BATF), which is a member of the AP-1 family, via Sirt1 expression, BATF deficiency inducing high levels of Sirt1 expression in memory CD8 T cells but not in naive CD8 T cells (Kuroda et al., 2011).

\section{IBM-BMT}

We reported that MRL/lpr mice possess abnormal radioresistant stem cells and have provided impressive evidence regarding the origin of ADs in this strain (Ikehara et al., 1989). BMT plus bone graft, which can recruit donor stroma cells, can prevent the recurrence of ADs (Ishida et al., 1994). However, allogeneic BMT + bone grafts failed to treat ADs in MRL/lpr mice, because these mice become more radiosensitive after the onset of lupus nephritis. Moreover, our previous reports showed that stroma cells can be trapped in the liver when BM cells are injected via the portal vein. Thus, directly injecting whole $\mathrm{BM}$ cells into the $\mathrm{BM}$, as in IBM-BMT, has been shown to be a powerful strategy for the treatment of ADs in MRL/lpr mice. IBM-BMT, which not only replaces HSCs but also MSCs, has been proven to be the best method for allogeneic BMT: (1) hematopoietic recovery is rapid because the MSCs directly home to the bone cavity, (2) the restoration of $\mathrm{T}$ cell functions is complete even in donor-recipient combinations across the MHC barriers, and (3) no graft failure occurs even if the radiation dose is reduced (Kushida et al., 2001). Moreover, IBM-BMT of young marrow cells reversed the reduction of pro-B cells and pre-B cells. The frequency of follicular-B cells in the IBM-BMT group was significantly increased compared to the old group (Hida et al., 2010). We have already used IBMBMT to successfully treat ADs, osteoporosis, diabetes, Alzheimer's disease, and for the induction of tolerance for organ transplantation (Takada et al., 2006; Guo et al., 2008; Kushida et al., 2009; Li et al., 2009, 2010) (Table 1).

BM cells mainly include HSCs and MSCs. MSCs are essential for supporting hematopoiesis in the BM. HSCs can normally proliferate in major histocompatibility complex (MHC)-compatible MSCs even in allogeneic microenvironments. Because the BMCs are directly injected into bone, IBM-BMT circumvents the risk of MSCs being trapped in the lung and liver. And because both MSCs and HSCs are transplanted, hematopoiesis can be rapidly restored. Moreover, IBM-BMT can prevent the risk of graft rejection, even with the use of a mild conditioning regimen (Kushida et al., 2001).

\section{IBM-BMT FOR TREATMENT OF RA}

$\mathrm{RA}$ is an $\mathrm{AD}$ that results in a chronic, systemic inflammatory disorder that may affect many tissues and organs. RA primarily affects joints, but it also affects other organs such heart, kidney, and blood vessels (Turesson et al., 2003). Its pathophysiology indicates that $\mathrm{TNF} \alpha$ drives synovial inflammation and joint destruction. The synovial cells include both fibroblast-like and macrophage-like synoviocytes. Fibroblast-like synoviocytes show abnormal behavior in RA (Scott et al., 2010). About 50\% of RA is caused by genetic abnormalities (van der Woude et al., 2009). The classification criteria for RA by the American College of Rheumatology (2010), and the treatment options, are summarized in the work by Scott et al (Scott et al., 2010). Here we talk about stem cell therapy for the treatment of RA in basic experiments and clinical applications.

$\mathrm{SKG} / \mathrm{Jcl}$ mice are a murine model for RA. BM cells of C57BL/6J mice were transplanted into $\mathrm{SKG} / \mathrm{Jcl}$ mice using IBM-BMT, and the hematolymphoid cells in the recipient mice were reconstituted by donor-derived cells. There was no evidence of arthritis 
Table 1 | IBM-BMT treatment of various diseases and induction of tolerance for organ transplantation.

\begin{tabular}{|c|c|c|}
\hline Authors & Animal model & Effect of IBM-BMT \\
\hline Li et al., 2012 & Mouse & Improve renal function \\
\hline Zhang et al., 2012 & Mouse & Prevention of leukemia \\
\hline Shi et al., 2011 & Mouse & Diminish risk of GVHD \\
\hline Feng et al., 2010 & Mouse & $\begin{array}{l}\text { Prevention of premature } \\
\text { ovarian failure }\end{array}$ \\
\hline Li et al., 2009 & Mouse & $\begin{array}{l}\text { Amelioration of cognitive } \\
\text { ability }\end{array}$ \\
\hline Kushida et al., 2009 & Mouse & $\begin{array}{l}\text { Prevention of rheumatoid } \\
\text { arthritis }\end{array}$ \\
\hline Okazaki et al., 2008 & Mouse & Liver transplantation \\
\hline Miyake et al., 2008 & Mouse & Prevention of GVHD \\
\hline Abraham et al., 2008 & Mouse & Prevention of type 2 diabetes \\
\hline Guo et al., 2008 & Rat & $\begin{array}{l}\text { Long-term donor specific } \\
\text { tolerance in cardiac allograft }\end{array}$ \\
\hline Feng et al., 2007 & Mouse & $\begin{array}{l}\text { Prevention of osteoporosis } \\
\text { and hypogonadism }\end{array}$ \\
\hline Koike et al., 2007 & Mouse & $\begin{array}{l}\text { Suppression of growth of } \\
\text { colon cancer cells }\end{array}$ \\
\hline $\begin{array}{l}\text { Ikebukuro et al., } \\
2006\end{array}$ & Mouse & $\begin{array}{l}\text { Tolerance induction in } \\
\text { allogeneic pancreatic islets }\end{array}$ \\
\hline Kaneda et al., 2005 & Rat & $\begin{array}{l}\text { Induction of tolerance for } \\
\text { lung transplantation }\end{array}$ \\
\hline Takada et al., 2006 & Mouse & $\begin{array}{l}\text { Prevention of senile } \\
\text { osteoporosis }\end{array}$ \\
\hline Taira et al., 2005 & Rat & Prevention of type 1 diabetes \\
\hline $\begin{array}{l}\text { Nakamura et al., } \\
2004\end{array}$ & Mouse & Prevention of GVHD \\
\hline Esumi et al., 2003 & Rat & $\begin{array}{l}\text { Induction of tolerance for } \\
\text { allogeneic leg transplantation }\end{array}$ \\
\hline Ichioka et al., 2002 & Mouse & $\begin{array}{l}\text { Prevention of senile } \\
\text { osteoporosis }\end{array}$ \\
\hline
\end{tabular}

in the SKG/Jcl mice at 12 months after transplantation. Moreover, IBM-BMT has been shown to normalize the percentages of Treg (Foxp3+/CD4+) cells, the percentages of receptor activator of $\mathrm{NF}-\mathrm{kB}$ ligand + cells on the CD4+ $\mathrm{T}$ cells and the serum levels of TNF $\alpha$, IL-1, and IL-6. One report demonstrated that IBM-BMT is a viable method of immunological manipulation that suppresses the severe joint destruction and bone absorption in SKG/Jcl mice and lends further credence to the use of this methodology in humans with intractable RA (Kushida et al., 2009). Human UC-derived MSCs have been discussed as a possible treatment for RA in the clinical setting. TNF $\alpha$ and IL-6 decreased and CD4+ CD25+ Foxp3 + T cells increased, in active RA patients after UC-derived MSCs were infused, and the UC-derived MSCs survived for 3-6 months, suggesting that treatment with MSCs would benefit RA patients (Wang et al., 2013). Expression of IL-17, IL-6, and TNF $\alpha$ were inhibited when allogeneic UC-derived MSCs were cultured with peripheral blood mononuclear cells (PBMCs) from RA patients, suggesting that MSCs can prevent the expression of these cytokines and that they have therapeutic potential in the treatment of RA (Wang et al., 2012).

\section{MALIGNANT TUMORS TREATED WITH IBM-BMT + THYMUS TRANSPLANTATION (TT)}

Donor lymphocyte infusion (DLI) is a useful method for the treatment of malignant tumors, but it also induces GVHD. However, IBM-BMT has been shown to prevent not only graft failure but also GVHD in animals, even when the radiation dose is reduced (Nakamura et al., 2004). Thus, IBM-BMT plus DLI were used to treat malignant tumors (fibrosarcomas) induced by a tumor cell line (methA). DLI (CD4- spleen cells) can prevent GVHD, but the tumor growth was not suppressed, indicating that $\mathrm{CD} 4+$ cells play important roles in graft-versus-tumor (GVT) and GVHD. Our previous results showed that IBM-BMT plus DLI (CD4- lymphocytes) suppressed not only GVHD but also tumor growth (Suzuki et al., 2005). Moreover, the combination of DC, IBM-BMT and DLI showed even better results than the combination of IBM-BMT and DLI in the treatment of solid tumors (Mukaide et al., 2007).

The thymus regulates the production, proliferation and functions of T cells. BMT + TT has been shown to be useful in the treatment of ADs in the MRL/Lpr mouse, because the allogeneic $\mathrm{T}$ cells newly-developed by TT are naïve T cells, which show less Fas expression and more resistance to apoptosis than the activated memory $\mathrm{T}$ cells with their high Fas expression. We found that the combination of allogeneic IBM-BMT + adult TT from the same donor is effective in mice with solid tumors, as it can induce high thymopoiesis, preserving strong GVT effects without inducing a severe graft-versus-host reaction (GVHR). Meth A sarcoma cells were subcutaneously inoculated into mice, and IBM-BMT + adult TT was then used to treat these mice when the tumor had grown to $5 \mathrm{~mm}$. In tumor-bearing mice, tumor growth was more strongly inhibited by IBM-BMT + adult TT than by IBM-BMT alone. The numbers of $\mathrm{CD} 8^{+} \mathrm{T}$ cells that infiltrated the tumors, and the number of apoptotic tumor cells, both significantly increased in the mice treated with IBM-BMT + adult TT. IBM-BMT + adult TT prevented tumor development with mild GVHR resulting from the induction of high thymopoiesis and a strong GVT effect in the tumor-bearing mice. The number of $\mathrm{CD}^{+}{ }^{+} \mathrm{FoxP}^{+}$cells was lower in the mice treated with IBM-BMT + adult TT than in those treated with IBM-BMT alone. Furthermore, the numbers of $\mathrm{CD}^{+}$cells infiltrating the tumor and the levels of IFN- $\gamma$ were higher in the mice treated with IBM-BMT + adult TT than in those treated with IBM-BMT alone (Miyake et al., 2009). Although T regs have been reported to suppress the GVHR induced by $\mathrm{CD} 4^{+} \mathrm{T}$ cells, they did not reduce the GVT induced by $\mathrm{CD}^{+}{ }^{+} \mathrm{T}$ cells (Edinger et al., 2003). Tumors were suppressed to a greater extent as a result of the increased $\mathrm{CD} 4^{+}$and $\mathrm{CD} 8^{+} \mathrm{T}$ cells and decreased number of $\mathrm{Gr}-$ $1^{+} / \mathrm{CD} 11 \mathrm{~b}^{+}$myeloid suppressor cells and Foxp $3^{+} / \mathrm{CD} 4^{+} \mathrm{T}$ regs, Moreover, the production of $\mathrm{CD} 62 \mathrm{~L}^{-} \mathrm{CD} 44^{+}$effector memory T cells and IFN- $\gamma$ were also higher (Zhang et al., 2011).

IBM-BMT seems to be better than co-transplantation of HSCs and cultured MSCs, mainly because the number of functional MSCs may drop after being cultured in vitro, and cultured MSCs also are trapped by the liver and lung in the case of IV-BMT. Umbilical cord blood (UCB) can also be used a source of stem cells for transplantation, although the numbers are generally insufficient to allow this to be used as a general source. IBM 
thus appears to be the best choice for allogeneic transplantation, despite the limited number of stem cells that can be directly transplanted into the bone cavity. In conclusion, IBM-BMT can efficiently transplant both HSCs and MSCs, is useful to treat intractable diseases such as RA and malignant tumors, and in the future may be useful for treating various intractable diseases.

\section{ACKNOWLEDGMENTS}

We would like to thank Mr. Hilary Eastwick-Field and Ms. Keiko Ando for their help in the preparation of the manuscript.

\section{REFERENCES}

Abraham, N. G., Li, M., Vanella, L., Peterson, S. J., Ikehara, S., and Asprinio, D. (2008). Bone marrow stem cell transplant into intra-bone cavity prevents type 2 diabetes: role of heme oxygenase-adiponectin. J. Autoimmun. 30, 128-135. doi: 10.1016/j.jaut.2007.12.005

Aggarwal, S., and Pittenger, M. F. (2005). Human mesenchymal stem cells modulate allogeneic immune cell responses. Blood 105, 1815-1822. doi: 10.1182/blood2004-04-1559

Aldinucci, A., Rizzetto, L., Pieri, L., Nosi, D., Romagnoli, P., Biagioli, T., et al. (2010). Inhibition of immune synapse by altered dendritic cell actin distribution: a new pathway of mesenchymal stem cell immune regulation. J. Immunol. 185, 5102-5110. doi: 10.4049/jimmunol.1001332

Anderson, M. S., and Bluestone, J. A. (2005). The NOD mouse: a model of immune dysregulation. Annu. Rev. Immunol. 23, 447-485. doi: 10.1146/annurev.immunol.23.021704.115643

Beyth, S., Borovsky, Z., Mevorach, D., Liebergall, M., Gazit, Z., Aslan, H., et al. (2005). Human mesenchymal stem cells alter antigen-presenting cell maturation and induce T-cell unresponsiveness. Blood 105, 2214-2219. doi: 10.1182/blood-2004-07-2921

Blander, G., and Guarente, L. (2004). The Sir2 family of protein deacetylases. Annu. Rev. Biochem. 73, 417-435. doi: 10.1146/annurev.biochem.73.011303.073651

Campagnoli, C., Roberts, I. A., Kumar, S., Bennett, P. R., Bellantuono, I., and Fisk, N. M. (2001). Identification of mesenchymal stem/progenitor cells in human first-trimester fetal blood, liver, and bone marrow. Blood 98, 2396-2402. doi: 10.1182/blood.V98.8.2396

Cohen-Kfir, E., Artsi, H., Levin, A., Abramowitz, E., Bajayo, A., Gurt, I., et al. (2011). Sirt1 is a regulator of bone mass and a repressor of Sost encoding for sclerostin, a bone formation inhibitor. Endocrinology 152, 4514-4524. doi: 10.1210/en.2011-1128

Deng, W., Han, Q., Liao, L., You, S., Deng, H., and Zhao, R. C. (2005). Effects of allogeneic bone marrow-derived mesenchymal stem cells on $\mathrm{T}$ and B lymphocytes from BXSB mice. DNA Cell Biol. 24, 458-463. doi: 10.1089/dna.2005.24.458

Ding, Y., Xu, D., Feng, G., Bushell, A., Muschel, R. J., and Wood, K. J. (2009). Mesenchymal stem cells prevent the rejection of fully allogenic islet grafts by the immunosuppressive activity of matrix metalloproteinase-2 and -9. Diabetes 58, 1797-1806. doi: 10.2337/db09-0317

Dominici, M., Le Blanc, K., Mueller, I., Slaper-Cortenbach, I., Marini, F., Krause, D., et al. (2006). Minimal criteria for defining multipotent mesenchymal stromal cells. The international society for cellular therapy position statement. Cytotherapy 8, 315-317. doi: 10.1080/14653240600855905

Edinger, M., Hoffmann, P., Ermann, J., Drago, K., Fathman, C. G., Strober, S., et al. (2003). CD4+CD25+ regulatory T cells preserve graft-versus-tumor activity while inhibiting graft-versus-host disease after bone marrow transplantation. Nat. Med. 9, 1144-1150. doi: 10.1038/nm915

English, K. (2013). Mechanisms of mesenchymal stromal cell immunomodulation. Immunol. Cell Biol. 91, 19-26. doi: 10.1038/icb.2012.56

English, K., Barry, F. P., Field-Corbett, C. P., and Mahon, B. P. (2007). IFN-gamma and TNF-alpha differentially regulate immunomodulation by murine mesenchymal stem cells. Immunol. Lett. 110, 91-100. doi: 10.1016/j.imlet.2007.04.001

English, K., Ryan, J. M., Tobin, L., Murphy, M. J., Barry, F. P., and Mahon, B. P. (2009). Cell contact, prostaglandin E(2) and transforming growth factor beta 1 play non-redundant roles in human mesenchymal stem cell induction of CD4+CD25(High) forkhead box P3+ regulatory T cells. Clin. Exp. Immunol. 156, 149-160. doi: 10.1111/j.1365-2249.2009.03874.x
Erices, A., Conget, P., and Minguell, J. J. (2000). Mesenchymal progenitor cells in human umbilical cord blood. Br. J. Haematol. 109, 235-242. doi: 10.1046/j.1365-2141.2000.01986.x

Esumi, T., Inaba, M., Ichioka, N., Kushida, T., Iida, H., and Ikehara, S. (2003). Successful allogeneic leg transplantation in rats in conjunction with intra-bone marrow injection of donor bone marrow cells. Transplantation 76, 1543-1548. doi: 10.1097/01.TP.0000081945.23698.5D

Feng, W., Cui, Y., Song, C., Zhan, H., Wang, X., Li, Q., et al. (2007). Prevention of osteoporosis and hypogonadism by allogeneic ovarian transplantation in conjunction with intra-bone marrow-bone marrow transplantation. Transplantation 84, 1459-1466. doi: 10.1097/01.tp.0000288182.75398.74

Feng, W., Cui, Y., Zhan, H., Shi, M., Cui, W., Guo, K., et al. (2010). Prevention of premature ovarian failure and osteoporosis induced by irradiation using allogeneic ovarian/bone marrow transplantation. Transplantation 89, 395-401. doi: 10.1097/TP.0b013e3181ca86bb

Fiorina, P., Jurewicz, M., Augello, A., Vergani, A., Dada, S., La Rosa, S., et al. (2009). Immunomodulatory function of bone marrow-derived mesenchymal stem cells in experimental autoimmune type 1 diabetes. J. Immunol. 183, 993-1004. doi: 10.4049/jimmunol.0900803

Gimble, J. M., Katz, A. J., and Bunnell, B. A. (2007). Adipose-derived stem cells for regenerative medicine. Circ. Res. 100, 1249-1260. doi: 10.1161/01.RES.0000265074.83288.09

Glennie, S., Soeiro, I., Dyson, P. J., Lam, E. W., and Dazzi, F. (2005). Bone marrow mesenchymal stem cells induce division arrest anergy of activated T cells. Blood 105, 2821-2827. doi: 10.1182/blood-2004-09-3696

Guo, K., Inaba, M., Li, M., An, J., Cui, W., Song, C., et al. (2008). Longterm donor-specific tolerance in rat cardiac allografts by intrabone marrow injection of donor bone marrow cells. Transplantation 85, 93-101. doi: 10.1097/01.tp.0000296061.71662.76

Haigis, M. C., and Sinclair, D. A. (2010). Mammalian sirtuins: biological insights and disease relevance. Annu. Rev. Pathol. 5, 253-295. doi: 10.1146/annurev.pathol.4.110807.092250

Hida, D., Ishiguro, N., Haneda, M., Ishida, Y., Suzuki, H., and Isobe, K. (2010). Intra-bone marrow bone marrow transplantation rejuvenates the B-cell lineage in aged mice. Immunol. Cell Biol. 88, 87-94. doi: 10.1038/icb.2009.69

Ichioka, N., Inaba, M., Kushida, T., Esumi, T., Takahara, K., Inaba, K., et al. (2002). Prevention of senile osteoporosis in SAMP6 mice by intrabone marrow injection of allogeneic bone marrow cells. Stem Cells 20, 542-551. doi: 10.1634/ stemcells.20-6-542

Ikebukuro, K., Adachi, Y., Suzuki, Y., Iwasaki, M., Nakano, K., Koike, Y., et al. (2006). Synergistic effects of injection of bone marrow cells into both portal vein and bone marrow on tolerance induction in transplantation of allogeneic pancreatic islets. Bone Marrow Transplant. 38, 657-664. doi: 10.1038/sj.bmt. 1705500

Ikehara, S. (2003). A novel strategy for allogeneic stem cell transplantation: perfusion method plus intra-bone marrow injection of stem cells. Exp. Hematol. 31 , 1142-1146. doi: 10.1016/j.exphem.2003.08.020

Ikehara, S., Yasumizu, R., Inaba, M., Izui, S., Hayakawa, K., Sekita, K., et al. (1989). Long-term observations of autoimmune-prone mice treated for autoimmune disease by allogeneic bone marrow transplantation. Proc. Natl. Acad. Sci. U.S.A. 86, 3306-3310.

Imai, S., and Guarente, L. (2010). Ten years of NAD-dependent SIR2 family deacetylases: implications for metabolic diseases. Trends Pharmacol. Sci. 31, 212-220. doi: 10.1016/j.tips.2010.02.003

Ishida, T., Inaba, M., Hisha, H., Sugiura, K., Adachi, Y., Nagata, N., et al. (1994). Requirement of donor-derived stromal cells in the bone marrow for successful allogeneic bone marrow transplantation. Complete prevention of recurrence of autoimmune diseases in MRL/MP-Ipr/Ipr mice by transplantation of bone marrow plus bones (stromal cells) from the same donor. J. Immunol. 152, 3119-3127.

Kaneda, H., Adachi, Y., Saito, Y., Ikebukuro, K., Machida, H., Suzuki, Y., et al. (2005). Long-term observation after simultaneous lung and intra-bone marrow-bone marrow transplantation. J. Heart Lung Transplant. 24, 1415-1423. doi: 10.1016/j.healun.2004.08.015

Koike, Y., Adachi, Y., Suzuki, Y., Iwasaki, M., Koike-Kiriyama, N., Minamino, K., et al. (2007). Allogeneic intrabone marrow-bone marrow transplantation plus donor lymphocyte infusion suppresses growth of colon cancer cells implanted in skin and liver of rats. Stem Cells 25, 385-391. doi: 10.1634/stemcells.20060227 
Kuroda, S., Yamazaki, M., Abe, M., Sakimura, K., Takayanagi, H., and Iwai, Y. (2011). Basic leucine zipper transcription factor, ATF-like (BATF) regulates epigenetically and energetically effector CD8 T-cell differentiation via Sirtl expression. Proc. Natl. Acad. Sci. U.S.A. 108, 14885-14889. doi: $10.1073 /$ pnas. 1105133108

Kushida, T., Inaba, M., Hisha, H., Ichioka, N., Esumi, T., Ogawa, R., et al. (2001). Intra-bone marrow injection of allogeneic bone marrow cells: a powerful new strategy for treatment of intractable autoimmune diseases in MRL/lpr mice. Blood 97, 3292-3299. doi: 10.1182/blood.V97.10.3292

Kushida, T., Ueda, Y., Umeda, M., Oe, K., Okamoto, N., Iida, H., et al. (2009). Allogeneic intra-bone marrow transplantation prevents rheumatoid arthritis in SKG/Jcl mice. J. Autoimmun. 32, 216-222. doi: 10.1016/j.jaut.2009. 02.015

Lee, R. H., Seo, M. J., Reger, R. L., Spees, J. L., Pulin, A. A., Olson, S. D., et al. (2006). Multipotent stromal cells from human marrow home to and promote repair of pancreatic islets and renal glomeruli in diabetic NOD/scid mice. Proc. Natl. Acad. Sci. U.S.A. 103, 17438-17443. doi: 10.1073/pnas.06082 49103

Li, M., Abraham, N. G., Vanella, L., Zhang, Y., Inaba, M., Hosaka, N., et al. (2010). Successful modulation of type 2 diabetes in $\mathrm{db} / \mathrm{db}$ mice with intra-bone marrow-bone marrow transplantation plus concurrent thymic transplantation. J. Autoimmun. 35, 414-423. doi: 10.1016/j.jaut.2010.09.001

Li, M., Inaba, M., Guo, K., Abraham, N. G., and Ikehara, S. (2009). Amelioration of cognitive ability in senescence-accelerated mouse prone 8 (SAMP8) by intrabone marrow-bone marrow transplantation. Neurosci. Lett. 465, 36-40. doi: 10.1016/j.neulet.2009.09.001

Li, M., Vanella, L., Zhang, Y., Shi, M., Takaki, T., Shapiro, J. I., et al. (2012). Stem cell transplantation increases antioxidant effects in diabetic mice. Int. J. Biol. Sci. 8, 1335-1344. doi: 10.7150/ijbs.4654

Makino, S., Fukuda, K., Miyoshi, S., Konishi, F., Kodama, H., Pan, J., et al. (1999). Cardiomyocytes can be generated from marrow stromal cells in vitro. J. Clin. Invest. 103, 697-705. doi: 10.1172/JCI5298

Matsuda-Hashii, Y., Takai, K., Ohta, H., Fujisaki, H., Tokimasa, S., Osugi, Y., et al. (2004). Hepatocyte growth factor plays roles in the induction and autocrine maintenance of bone marrow stromal cell IL-11, SDF-1 alpha, and stem cell factor. Exp. Hematol. 32, 955-961. doi: 10.1016/j.exphem.2004. 06.012

Miyake, T., Hosaka, N., Cui, W., Nishida, T., Takaki, T., Inaba, M., et al. (2009). Adult thymus transplantation with allogeneic intra-bone marrow-bone marrow transplantation from same donor induces high thymopoiesis, mild graftversus-host reaction and strong graft-versus-tumour effects. Immunology 126 552-564. doi: 10.1111/j.1365-2567.2008.02920.x

Miyake, T., Inaba, M., Fukui, J., Ueda, Y., Hosaka, N., Kamiyama, Y., et al. (2008). Prevention of graft-versus-host disease by intrabone marrow injection of donor T cells: involvement of bone marrow stromal cells. Clin. Exp. Immunol. 152, 153-162. doi: 10.1111/j.1365-2249.2008.03615.x

Mukaide, H., Adachi, Y., Koike-Kiriyama, N., Suzuki, Y., Minamino, K., Iwasaki, M., et al. (2007). Immunotherapy for malignant tumors using combination of allogeneic intra-bone marrow-bone marrow transplantation, donor lymphocyte infusion and dendritic cells. Int. J. Oncol. 30, 1309-1315.

Nakamura, K., Inaba, M., Sugiura, K., Yoshimura, T., Kwon, A. H., Kamiyama, Y., et al. (2004). Enhancement of allogeneic hematopoietic stem cell engraftment and prevention of GVHD by intra-bone marrow bone marrow transplantation plus donor lymphocyte infusion. Stem Cells 22, 125-134. doi 10.1634/stemcells.22-2-125

Nishimura, M., Toki, J., Sugiura, K., Hashimoto, F., Tomita, T., Fuiishima, H., et al. (1994). Focal segmental glomerular sclerosis, a type of intractable chronic glomerulonephritis, is a stem cell disorder. J. Exp. Med. 179, 1053-1058.

Okazaki, S., Hisha, H., Mizokami, T., Takaki, T., Wang, X., Song, C., et al. (2008). Successful acceptance of adult liver allografts by intra-bone marrowbone marrow transplantation. Stem Cells Dev. 17, 629-639. doi: 10.1089/scd. 2007.0218

Peltz, L., Gomez, J., Marquez, M., Alencastro, F., Atashpanjeh, N., Quang, T., et al. (2012). Resveratrol exerts dosage and duration dependent effect on human mesenchymal stem cell development. PLoS ONE 7:e37162. doi: 10.1371/journal.pone. 0037162

Poloni, A., Maurizi, G., Leoni, P., Serrani, F., Mancini, S., Frontini, A., et al. (2012). Human dedifferentiated adipocytes show similar properties to bone marrowderived mesenchymal stem cells. Stem Cells 30, 965-974. doi: 10.1002/stem.1067
Puri, N., Sodhi, K., Haarstad, M., Kim, D. H., Bohinc, S., Foglio, E., et al. (2012). Heme induced oxidative stress attenuates sirtuin 1 and enhances adipogenesis in mesenchymal stem cells and mouse pre-adipocytes. J. Cell. Biochem. 113, 1926-1935. doi: 10.1002/jcb.24061

Ramasamy, R., Fazekasova, H., Lam, E. W., Soeiro, I., Lombardi, G., and Dazzi, F. (2007). Mesenchymal stem cells inhibit dendritic cell differentiation and function by preventing entry into the cell cycle. Transplantation $83,71-76$. doi: 10.1097/01.tp.0000244572.24780.54

Ryan, J. M., Barry, F., Murphy, J. M., and Mahon, B. P. (2007). Interferon-gamma does not break, but promotes the immunosuppressive capacity of adult human mesenchymal stem cells. Clin. Exp. Immunol. 149, 353-363. doi: 10.1111/j.13652249.2007.03422.x

Schurgers, E., Kelchtermans, H., Mitera, T., Geboes, L., and Matthys, P. (2010). Discrepancy between the in vitro and in vivo effects of murine mesenchymal stem cells on T-cell proliferation and collagen-induced arthritis. Arthritis Res. Ther. 12, R31. doi: 10.1186/ar2939

Scott, D. L., Wolfe, F., and Huizinga, T. W. (2010). Rheumatoid arthritis. Lancet 376, 1094-1108. doi: 10.1016/S0140-6736(10)60826-4

Shi, M., Adachi, Y., Cui, Y., Li, M., Lian, Z., Zhang, Y., et al. (2011). Combination of intra-bone marrow-bone marrow transplantation and subcutaneous donor splenocyte injection diminishes risk of graft-versus-host disease and enhances survival rate. Stem Cells Dev. 20, 759-768. doi: 10.1089/scd.2010. 0232

Simic, P., Zainabadi, K., Bell, E., Sykes, D. B., Saez, B., Lotinun, S., et al. (2013). SIRT1 regulates differentiation of mesenchymal stem cells by deacetylating betacatenin. EMBO Mol. Med. 5, 430-440. doi: 10.1002/emmm.201201606

Sotiropoulou, P. A., Perez, S. A., Gritzapis, A. D., Baxevanis, C. N., and Papamichail, M. (2006). Interactions between human mesenchymal stem cells and natural killer cells. Stem Cells 24, 74-85. doi: 10.1634/stemcells.2004-0359

Suzuki, Y., Adachi, Y., Minamino, K., Zhang, Y., Iwasaki, M., Nakano, K., et al. (2005). A new strategy for treatment of malignant tumor: intra-bone marrowbone marrow transplantation plus CD4- donor lymphocyte infusion. Stem Cells 23, 365-370. doi: 10.1634/stemcells.2004-0258

Taira, M., Inaba, M., Takada, K., Baba, S., Fukui, J., Ueda, Y., et al. (2005). Treatment of streptozotocin-induced diabetes mellitus in rats by transplantation of islet cells from two major histocompatibility complex disparate rats in combination with intra bone marrow injection of allogeneic bone marrow cells. Transplantation 79, 680-687. doi: 10.1097/01.TP.0000155500.17348.94

Takada, K., Inaba, M., Ichioka, N., Ueda, Y., Taira, M., Baba, S., et al. (2006). Treatment of senile osteoporosis in SAMP6 mice by intra-bone marrow injection of allogeneic bone marrow cells. Stem Cells 24, 399-405. doi: 10.1634/stemcells.2005-0068

Tang, D. Q., Cao, L. Z., Burkhardt, B. R., Xia, C. Q., Litherland, S. A., Atkinson, M. A., et al. (2004). In vivo and in vitro characterization of insulin-producing cells obtained from murine bone marrow. Diabetes 53, 1721-1732. doi: 10.2337/diabetes.53.7.1721

Trim, N., Morgan, S., Evans, M., Issa, R., Fine, D., Afford, S., et al. (2000). Hepatic stellate cells express the low affinity nerve growth factor receptor p75 and undergo apoptosis in response to nerve growth factor stimulation. Am. J. Pathol. 156, 1235-1243. doi: 10.1016/S0002-9440(10) 64994-2

Tseng, P. C., Hou, S. M., Chen, R. J., Peng, H. W., Hsieh, C. F., Kuo, M. L., et al. (2011). Resveratrol promotes osteogenesis of human mesenchymal stem cells by upregulating RUNX2 gene expression via the SIRT1/FOXO3A axis. J. Bone Miner. Res. 26, 2552-2563. doi: 10.1002/jbmr.460

Turesson, C., O'Fallon, W. M., Crowson, C. S., Gabriel, S. E., and Matteson, E. L. (2003). Extra-articular disease manifestations in rheumatoid arthritis: incidence trends and risk factors over 46 years. Ann. Rheum. Dis. 62, 722-727. doi: 10.1136/ard.62.8.722

Uccelli, A., Moretta, L., and Pistoia, V. (2008). Mesenchymal stem cells in health and disease. Nat. Rev. Immunol. 8, 726-736. doi: 10.1038/nri2395

Urban, V. S., Kiss, J., Kovacs, J., Gocza, E., Vas, V., Monostori, E., et al. (2008). Mesenchymal stem cells cooperate with bone marrow cells in therapy of diabetes. Stem Cells 26, 244-253. doi: 10.1634/stemcells.2007-0267

van der Woude, D., Houwing-Duistermaat, J. J., Toes, R. E., Huizinga, T. W., Thomson, W., Worthington, J., et al. (2009). Quantitative heritability of anti-citrullinated protein antibody-positive and anti-citrullinated protein antibody-negative rheumatoid arthritis. Arthritis Rheum. 60, 916-923. doi: $10.1002 /$ art.24385 
van Poll, D., Parekkadan, B., Cho, C. H., Berthiaume, F., Nahmias, Y., Tilles, A. W., et al. (2008). Mesenchymal stem cell-derived molecules directly modulate hepatocellular death and regeneration in vitro and in vivo. Hepatology 47, 1634-1643. doi: 10.1002/hep. 22236

Wang, Q., Li, X., Luo, J., Zhang, L., Ma, L., Lv, Z., et al. (2012). The allogeneic umbilical cord mesenchymal stem cells regulate the function of Thelper 17 cells from patients with rheumatoid arthritis in an in vitro co-culture system. BMC Musculoskelet. Disord. 13:249. doi: 10.1186/1471-2474-13-249

Wang, L., Cong, X., Liu, G., Zhou, J., Bai, B., Li, Y., et al. (2013). Human umbilical cord mesenchymal stem cell therapy for patients with active rheumatoid arthritis: safety and efficacy. Stem Cells Dev. 22, 3192-3202. doi: $10.1089 / \mathrm{scd} .2013 .0023$

Yao, C., Sakata, D., Esaki, Y., Li, Y., Matsuoka, T., Kuroiwa, K., et al. (2009). Prostaglandin E2-EP4 signaling promotes immune inflammation through Th1 cell differentiation and Th17 cell expansion. Nat. Med. 15, 633-640. doi: 10.1038/nm.1968

Yokokawa, M., Ohnishi, S., Ishibashi-Ueda, H., Obata, H., Otani, K., Miyahara, Y., et al. (2008). Transplantation of mesenchymal stem cells improves atrioventricular conduction in a rat model of complete atrioventricular block. Cell Transplant. 17, 1145-1155. doi: 10.3727/096368908787236594

Zappia, E., Casazza, S., Pedemonte, E., Benvenuto, F., Bonanni, I., Gerdoni, E., et al. (2005). Mesenchymal stem cells ameliorate experimental autoimmune encephalomyelitis inducing T-cell anergy. Blood 106, 1755-1761. doi: 10.1182/blood-2005-04-1496

Zhang, B., Liu, R., Shi, D., Liu, X., Chen, Y., Dou, X., et al. (2009). Mesenchymal stem cells induce mature dendritic cells into a novel Jagged-2-dependent regulatory dendritic cell population. Blood 113, 46-57. doi: 10.1182/blood-2008-04154138

Zhang, Y., Hosaka, N., Cui, Y., Shi, M., and Ikehara, S. (2011). Effects of allogeneic hematopoietic stem cell transplantation plus thymus transplantation on malignant tumors: comparison between fetal, newborn, and adult mice. Stem Cells Dev. 20, 599-607. doi: 10.1089/scd.2010.0230

Zhang, Y., Hosaka, N., Cui, Y., Shi, M., Li, M., Li, Q., et al. (2012). Effects of intrabone marrow-bone marrow transplantation plus adult thymus transplantation on survival of mice bearing leukemia. Stem Cells Dev. 21, 1441-1448. doi: $10.1089 / \mathrm{scd} .2011 .0358$

Zhao, D. C., Lei, J. X., Chen, R., Yu, W. H., Zhang, X. M., Li, S. N., et al. (2005). Bone marrow-derived mesenchymal stem cells protect against experimental liver fibrosis in rats. World J. Gastroenterol. 11, 3431-3440.

Zuk, P. A., Zhu, M., Mizuno, H., Huang, J., Futrell, J. W., Katz, A. J., et al. (2001) Multilineage cells from human adipose tissue: implications for cell-based therapies. Tissue Eng. 7, 211-228. doi: 10.1089/107632701300062859

Conflict of Interest Statement: The authors declare that the research was conducted in the absence of any commercial or financial relationships that could be construed as a potential conflict of interest.

Received: 12 June 2014; accepted: 15 August 2014; published online: 02 September 2014

Citation: Li M, Guo K and Ikehara S (2014) Intractable diseases treated with intrabone marrow-bone marrow transplantation. Front. Cell Dev. Biol. 2:48. doi: 10.3389/ fcell.2014.00048

This article was submitted to Stem Cell Research, a section of the journal Frontiers in Cell and Developmental Biology.

Copyright (c) 2014 Li, Guo and Ikehara. This is an open-access article distributed under the terms of the Creative Commons Attribution License (CC BY). The use, distribution or reproduction in other forums is permitted, provided the original author(s) or licensor are credited and that the original publication in this journal is cited, in accordance with accepted academic practice. No use, distribution or reproduction is permitted which does not comply with these terms. 